\title{
New state record and geographic distribution map of Rhinella inopina Vaz-Silva, Valdujo \& Pombal, 2012 (Anura: Bufonidae)
}

\author{
Larissa Ferreira Arruda*, Marco Antônio de Amorim Peixoto, Carla da Silva Guimarães, João Victor \\ Andrade Lacerda and Renato Neves Feio

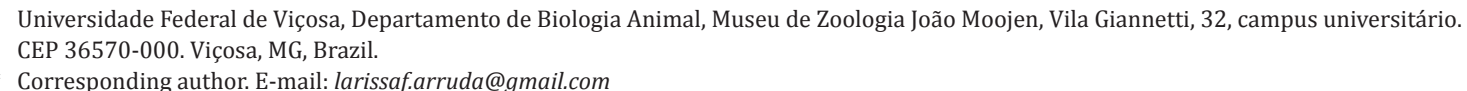

\begin{abstract}
We provide the first record of Rhinella inopina in the state of Minas Gerais, southeastern Brazil, in municipalities of Bonito de Minas and Januária. It is also the species southernmost record, extending its known geographic distribution in about 170 and $210 \mathrm{~km}$ respectively southeastward its closest previously record, in municipality of Sítio d'Abadia, State of Goiás, Central Brazil.
\end{abstract}

The Rhinella crucifer species group was first suggested by Duellman and Schulte (1992) and later confirmed by Baldissera et al. (2004) based on osteological and external morphology, being currently composed by six species: Rhinella abei (Baldissera, Caramaschi \& Haddad, 2004), R. crucifer (Wied-Neuwied, 1821), R. henseli (Lutz, 1934), $R$. inopina Vaz-Silva, Valdujo \& Pombal, 2012, R. ornata (Spix 1824) and R. pombali (Baldissera, Caramaschi \& Haddad, 2004). The $R$. crucifer species group has a wide distribution (Haddad and Sazima 1992) occurring in the Atlantic rainforest, Cerrado and transitional areas between these domains (Baldissera et al. 2004; Thomé et al. 2010). New genetic studies suggest the existence only of five species in the group mentioned here and show evidences of hybridization. The same study found only in species $R$. henseli and $R$ inopina correlation between its current distribution and genetic units (Thomé et al. 2012).

Rhinella inopina was recently described from municipalities of São Domingos (13 $23^{\prime} 40^{\prime \prime}$ S; $46^{\circ} 19^{\prime} 35^{\prime \prime}$ W) and Sítio D'Abadia (14 $\left.48^{\prime} 26^{\prime \prime} \mathrm{S}, 46^{\circ} 15^{\prime} 03^{\prime \prime} \mathrm{W}\right)$, both in the state of Goiás, Combinado $\left(12^{\circ} 47^{\prime} 33^{\prime \prime} \mathrm{S}, 46^{\circ} 32^{\prime} 16^{\prime \prime}\right.$ W) and Aurora do Tocantis (12 $\left.42^{\prime} 36^{\prime \prime} \mathrm{S}, 46^{\circ} 24^{\prime} 15^{\prime \prime} \mathrm{W}\right)$, in the state of Tocantis, and São Desidério $\left(12^{\circ} 21^{\prime} 07^{\prime \prime}\right.$ S, $44^{\circ} 59^{\prime} 03^{\prime \prime} \mathrm{W}$ ), state of Bahia, having the most inland distribution with the $R$. crucifer species group and apparently endemic to the disjunction Seasonal Tropical Dry Forests enclaves in western Cerrado (Vaz-Silva et al. 2012). Herein we provide two new records of $R$. inopina from the municipalities of Bonito de Minas and Januária, both in the state of Minas Gerais, southeastern Brazil, being the first state record and bringing to seven the number of records of the species.

Our report was based on five specimens of Rhinella inopina deposited in the herpetological collection of Museu de Zoologia João Moojen, from Universidade Federal de Viçosa, state of Minas Gerais. Four specimens (MZUFV 4932-4935) were collected at the Parque Nacional Cavernas do Peruaçu, municipality of Januária $\left(15^{\circ} 07^{\prime} 44^{\prime \prime} \mathrm{S}, 44^{\circ} 17^{\prime} 06^{\prime \prime} \mathrm{W}\right)$, state of Minas Gerais and one (MZUFV 9269) in the Área de Proteção Ambiental do Rio Pandeiros (APA Pandeiros), municipality of Bonito de Minas $\left(15^{\circ} 21^{\prime} 27^{\prime \prime} \mathrm{S}, 44^{\circ} 45^{\prime} 45^{\prime \prime} \mathrm{W}\right)$ state of Minas Gerais, both inside the Cerrado biome.

Although the preserved specimens were previously identified as Rhinella pombali, we noticed they perfectly fit on the diagnosis of $R$. inopina provided by Vaz-Silva et al. (2012), differing from all other species from the $R$. crucifer group by having an oblique arrangement of the parotoid gland in relation to midline of the body (Figure 1).

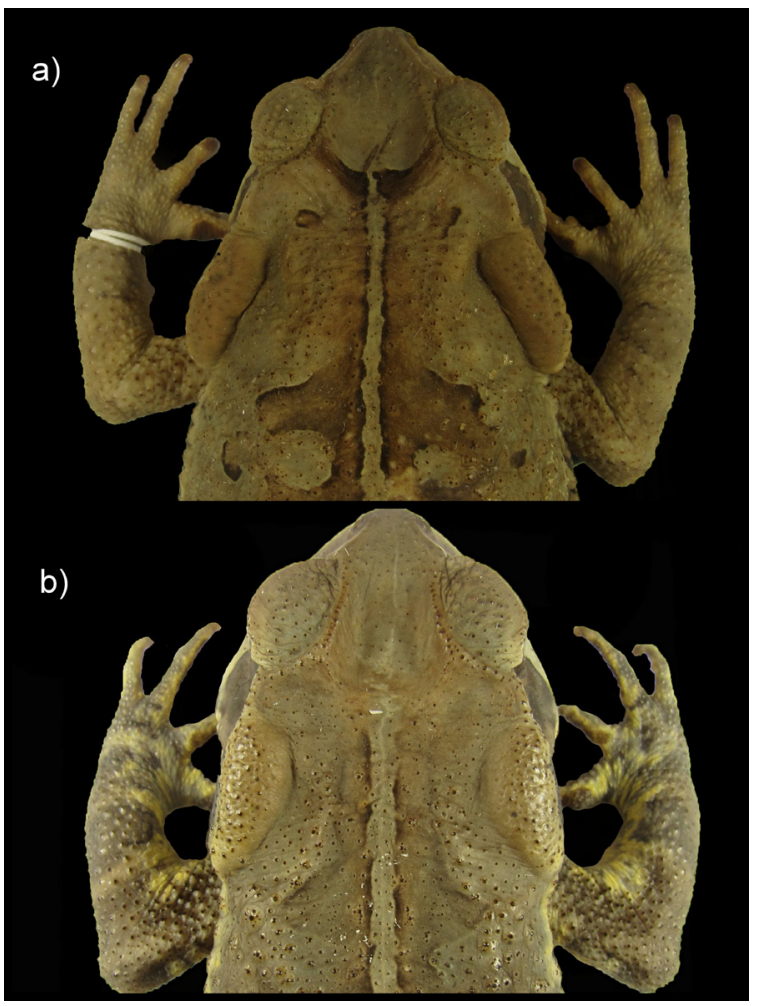

FigurE 1. Comparative dorsal view of Rhinella inopina, CRC 9,4 cm (a) and Rhinella pombali, CRC $8,5 \mathrm{~cm}$ (b), with emphasis on the oblique arrangement of the parotoid gland in relation to the midline of the body in $R$. inopina (exclusive of this species). 
Besides the first state record, the occurrence of Rhinella inopina in the municipality of Bonito de Minas represents the species southernmost record, extending its known distribution in ca. $270 \mathrm{~km}$ from its type locality (220 to the south and 150 to the east) and $170 \mathrm{~km}$ from the closest previously known record in Sítio D’Abadia, state of Goias. The occurrence of $R$. inopina in Januária is also relevant as it becomes the species westernmost record, extending its distribution in $290 \mathrm{~km}$ from its type locality and $210 \mathrm{~km}$ from its closest previously known record (Figure 2).

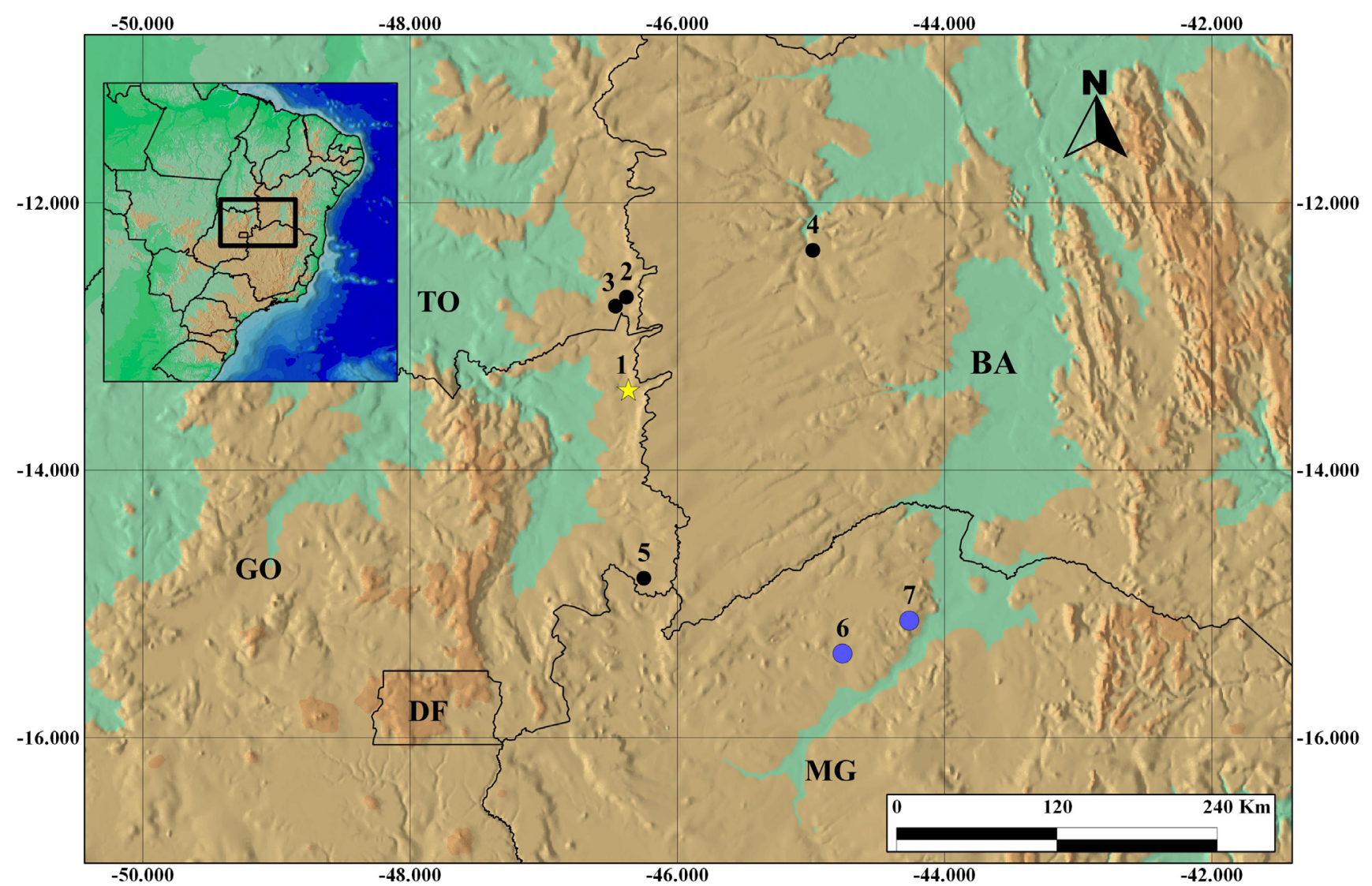

FIGURE 2. Geographic distribution map of the Rhinella inopina. (1) São Domingos (GO); (2) Aurora do Tocantins (TO); (3) Combinado (TO); (4) São Desidério (BA); (5) Sítio d’Abadia (GO); (6) Bonito de Minas (MG); (7) Januária (MG). Yellow star: type locality. Blue circles: records from the present study. Black circles: records from Vaz-Silva et al. (2012). Map by M.A.A. Peixoto.

ACKNOWLEDGMENTS: JVL is grateful to Coordenação de Aperfeiçoamento de Pessoal de Nível Superior (CAPES) for his current MSc. Scholarship; CSG is grateful to Fundação de Amparo à pesquisa do Estado de Minas Gerais (FAPEMIG) for his current scholarship. RNF thanks the Conselho Nacional de Desenvolvimento Científico e Tecnológico (CNPq) for his productivity fellowship; MAAP also thanks CNPq for his fellowship.

\section{Literature Cited}

Baldissera Jr., F.A.B., U. Caramaschi and C.F.B. Haddad. 2004. Review of the Bufo crucifer species group, with descriptions of two new related species (Amphibia, Anura, Bufonidae). Arquivos do Museu Nacional 62(3): 255-282.

Duellman, W.E. and R. Schulte. 1992. Description of a new species of Bufo from Northern Peru with comments on phonetic groups of South American toads (Anura: Bufonidae). Copeia 1992(1): 162-172.

Haddad, C.F.B. and I. Sazima. 1992. Anfíbios anuros da Serra do Japi; pp. 188-211, in: L.P.C. Morelato (ed.). História Natural da Serra do Japi: Ecologia e Preservação de uma Área Florestal no Sudeste do Brasil. Campinas: Editora da Unicamp.
Thomé, M.T.C., K.R. Zamudio, J.G.R. Giovanelli, C.F.B. Haddad, F.A. Baldissera Jr. and J. Alexandrino. 2010. Phylogeography of endemic toads and post-Pliocene persistence of the Brazilian Atlantic Forest. Molecular Phylogenetics and Evolution 55(3): 1018-1031.

Thomé, M.T.C., K.R. Zamudio and J. Alexandrino. 2012. Delimiting genetic units in Neotropical toads under incomplete lineage sorting and hybridization. BMC Evolutionary Biology 12: 242.

Vaz-Silva, W., P.H. Valdujo and J.P. Pombal Jr. 2012. New species of the Rhinella crucifer group from the Brazilian Cerrado. (Anura, Bufonidae) from the Brazilian Cerrado. Zootaxa 3265: 57-65.

RECEIVED: August 2013

ACCEPTED: January 2014

Published ONLINE: May 2014

EDITORIAL RESPONSIBILITY: Raúl Maneyro 